\title{
Consumers' Online Information And Opinion Search Behaviors: A Research On The X And Y Generation Of Consumers ${ }^{1}$
}

\author{
Serkan KILIÇ \\ Uludag University Economics \\ and Administrative Sciences \\ Faculty, Business \\ Administration Department, \\ Nilüfer, Bursa, Turkey \\ skilic@uludag.edu.tr
}

\author{
Erkan ÖZDEMİR \\ Uludag University Economics \\ and Administrative Sciences \\ Faculty, Business \\ Administration Department, \\ Nilüfer, Bursa, Turkey \\ eozdemir@uludag.edu.tr
}

\author{
Hande ARIKAN KILIÇ \\ Uludag University Vocational \\ School of Mustafakemalpaşa, \\ Marketing Programme, \\ Mustafakemalpaşa, Bursa, \\ Turkey \\ arikanh@uludag.edu.tr
}

\begin{abstract}
The internet, which is an important source of information and opinions today, is a significant external information source that the consumers consult prior to their decisions to make purchases. Consumers' information and opinion search behaviors are influenced by many factors. One of these factors is the concept of generation that the individuals are inherently a member of. It is crucially important for the success of both offline and online companies to be aware of the online information and opinion search behavior of the $\mathrm{X}$ and $\mathrm{Y}$ generation consumers who are the most important internet users and shoppers of today. The purpose of this paper is to investigate whether there exist differences in online information and opinion search behaviors according to the generation of the respondents as consumers. For the main purpose, a questionnaire was designed from the literature review, and data were collected from the $\mathrm{X}$ and $\mathrm{Y}$ generations of consumers. Analyses of chi-square, factor analyses, and t-tests were conducted for hypotheses testing. The results of study show that three online information and opinion search behaviors are different by consumers' generation. These generation-based differences include avoiding risks, obtaining instant information and opinions and convenience in online information and opinion search. The main value of this paper is the empirical analyses of the consumers' online information and opinion search behaviors from $\mathrm{X}$ and $\mathrm{Y}$ generations perspective. As far as the relevant literature is concerned, the literature regarding online information search has come to emerge; however, there seems to be a gap in the literature whether there are differences on this subject from the perspectives of consumers in the $\mathrm{X}$ and $\mathrm{Y}$ generations. The present study aims to fill in this gap.
\end{abstract}

Keywords: Marketing to Generations, X Generation, Y Generation, Online Information and Opinion Search, E-marketing, Turkey

\footnotetext{
${ }^{1}$ This Manuscript was expanded from The Small Sized Research Project Numbered KUAP (I) - 2015/32, Titled "Consumers' Online Information Search Behaviors: A Research on the X and Y Generation of Consumers" and was Supported by The Scientific Research Projects Unit of Uludag University.
} 


\section{Introduction}

The internet is an ever-growing global communication network and plays a crucial role in the process of obtaining, storing and sharing information. It is possible to access all sorts of information with ease and great speed via the internet. Consumers analyze the comments made on the goods and services on the internet during process of purchase, keep themselves up to date with the latest promotions and even get the chance of benefiting from the special promotions made available for online shopping. Widespread use of the internet today has influenced the information search process before making their decisions to purchase goods. The consumers who collected information regarding the goods and services previously purchased via visits to shops or the recommendations of acquaintances or reliable people have started to use the internet increasingly more and more for all these transactions. Since the internet is a consumeroriented information medium (Hodkinson et al., 2000), it minimizes the perceived risk for the consumers, offer new opportunities in obtaining goods-related information and the perceived low search costs increase the use of the internet for making searches for relevant information (Jepsen, 2007: 22-23). Therefore, before making a decision to make a purchase, consumers are involved in making information searches on the internet. These searches include analyzing the official web sites of companies, getting involved in the discussion groups on the internet, following the discussions or communication with the others via e-mails.

Many consumers today carry out searches on the internet about the goods and services they wish to purchase. Consumers' online information search behaviors were investigated in terms of such different sectors as health (Cotten and Gupta, 2004; Diaz et al., 2002; Eysenbach and Köhler, 2002; Morahan-Martin; 2004), tourism (Fodness and Murray, 1997, 1999; Pan and Fesenmaier, 2006; Ho et al., 2012), finance (Ramaswani et al., 2000), and automobiles (Kiel and Layton, 1981; Klein and Ford, 2003). Similarly, consumers' online information search behaviors were investigated in many studies (Degeratu et al., 2000; Hodkinson et al., 2000; Zhang et al., 2006; Goldsmith and Horowitz: 2006; Grant et al., 2007) such as age (Yoon, 1997; Dholakia and Uusitalo, 2002; Saigal and Mann, 2010; Sorce et al., 2005), and gender (Barber et al., 2009; Bhatnagar and Ghose, 2004; Cotten and Gupta, 2004; Dittmar et al. 2004; Park et al., 2009). As far as the studies on online information search behavior in Turkey are concerned, it is clearly seen that the number of studies are insufficient and those studies concerned (Yalçınalp and Askar, 2003; Kurulgan and Argan, 2007; Okay, 2010; Ekici and Uçak, 2012; Geçer and İra, 2014) mainly used students samples as subjects.

The differences in consumers' efforts to obtain information over the internet may not only be explicated by the sectoral or demographic variables. The concept of generation that has been under much debate in recent years should also be investigated. It is because individuals tend to demonstrate the behaviors of the generation they belong to. This particular situation entails the marketing managements to know the characteristics of generations and develop marketing practices based on this. The purpose of the present study is to investigate online information and opinion search behaviors of the consumers in the $\mathrm{X}$ and $\mathrm{Y}$ generation in their process of making a purchase and based on the results of the study, make recommendations to the business managers. The reason why the $\mathrm{X}$ and $\mathrm{Y}$ generation was chosen for this study is the fact that the individuals in the generations today have an important purchasing power as consumers and have a significantly high number and percentage within the population 
in Turkey. For instance, based on the results of TÜİK's Address-Based Population Registration System numbered 21507 and dated 28.01.2016 (http://www.tuik.gov.tr /OncekiHBArama.do, access date: 17.10.2016), Turkey's population as of the end of 2015 is 78.741.053. When the data of 2015 is analyzed, population of the X generation (those born between the dates of 1960-1980), in other words, those aged 55-35 (inclusive) is 20.978.891. In other words, the proportion of those in the $\mathrm{X}$ generation within the population of Turkey is $26,64 \%$. Population of the Y generation (those born between the dates of 1981-2000), in other words, those aged 34-15 (inclusive) is 25.591.066. In other words, the proportion of those in the $Y$ generation within the population of Turkey is $59,14 \%$.

In the study, initially the relevant literature regarding the generations and their characteristics, their use of internet and technology, and consumers' online information search processes will be examined. Then, studies and their results regarding the $\mathrm{X}$ and $\mathrm{Y}$ generations and online information and opinion search behaviors during the process of purchasing of those consumers in these generations will be investigated. Results of the study will reveal to what extent the online information and opinion search behaviors in the $\mathrm{X}$ and $\mathrm{Y}$ generations differ from one another. In the conclusion section of the study, the results obtained from this study will be compared with those available in the relevant literature and recommendations will be made to the business managers. When the relevant literature is examined, it is seen that literature on information search and online information search has come to emerge; however, there is a gap in the literature whether there are differences on this subject from the perspectives of consumers in the $\mathrm{X}$ and $\mathrm{Y}$ generations. The aim of the present study is not only to fill in this gap, but also to make significant contributions to the success of those businesses that targeting the $\mathrm{X}$ and $\mathrm{Y}$ generations.

\section{Literature Review}

\subsection{The Generations and Their Characteristics}

When the classification of generations today is examined, it is seen that different dates are used in the literature. However, when many different sources are examined, basically five different generations come into prominence as is clearly seen in table 1 . There are explicated as; the silent generation (traditionalists), baby boomer generation, the $\mathrm{X}$ generation, the $\mathrm{Y}$ generation and the $\mathrm{Z}$ generation. The fact that all these generations that have quite distinct characteristics live together may cause the marketing managers to face difficulties in their decisions. In order to overcome these difficulties, it is crucially important to know the different behaviors of these generations as consumers. 
Table 1: The generations based on their dates of birth

\begin{tabular}{|l|c|c|c|c|c|}
\hline Authors & $\begin{array}{c}\text { The Silent } \\
\text { Generation } \\
\text { (Traditionalists) }\end{array}$ & $\begin{array}{c}\text { The Baby- } \\
\text { Boomer } \\
\text { Generation }\end{array}$ & $\begin{array}{c}\text { The X } \\
\text { Generation }\end{array}$ & $\begin{array}{c}\text { The Y } \\
\text { Generation }\end{array}$ & $\begin{array}{c}\text { The Z } \\
\text { Generation }\end{array}$ \\
\hline Keleş, 2011 & & $1946-1964$ & $1965-1979$ & $1980-1999$ & \\
\hline Yelkikalan et al., 2010 & $1925-1945$ & $1946-1964$ & $1965-1979$ & $1980-1994$ & \\
\hline Williams and Page, 2011 & $1930-1945$ & $1946-1964$ & $1965-1976$ & $1977-1994$ & 1994 and later \\
\hline Senbir, 2004 & $1929-1939$ & $1945-1965$ & $1965-1977$ & $1977-1994$ & 2003 and later \\
\hline Adigüzel et al., 2014 & $1925-1945$ & $1946-1964$ & $1965-1979$ & $1980-2001$ & $2000-2020$ \\
\hline Schullery, 2013 & $1925-1945$ & $1946-1964$ & $1965-1981$ & $1982-1999$ & \\
\hline Bolton et al., 2013 & $1925-1945$ & $1946-1960$ & $1961-1981$ & $1981-1999$ & \\
\hline Kupperschmidt, 2000 & & $1940-1960$ & $1961-1980$ & $1981-2000$ & \\
\hline Parry and Urwin, 2011 & & $1943-1960$ & $1961-1981$ & 1982 and later & \\
\hline Ayhün, 2013 & 1945 and before & $1946-1964$ & $1965-1979$ & $1980-1994$ & 2003 and later \\
\hline McFadden, 2011-2012 & 1946 and before & $1946-1964$ & $1965-1981$ & 1980 and later & \\
\hline $\begin{array}{l}\text { Anantatmula and } \\
\text { Shrivastav, 2012 }\end{array}$ & $1922-1945$ & $1946-1964$ & $1965-1979$ & $1980-2001$ & \\
\hline Tsui, 2001 & $1925-1945$ & $1946-1964$ & $1961-1981$ & $1976-1981$ & \\
\hline Salahuddin, 2010 & $1922-1943$ & $1943-1960$ & $1960-1980$ & $1980-2000$ & \\
\hline
\end{tabular}

The generations have some significant characteristics that also cause the marketing strategies of businesses to take shape. In relation to the purpose of the present study, the generations and their intrinsic characteristics are briefly explicated below:

The Silent Generation (Traditionalists): The silent generation also referred to as the traditionalists or the mature generation is generally comprised of those born between the years 1925 and 1945. The silent generation is more cautious against those situations they are unsure about and reluctant to take risks against them due to the suppression caused by some important event that took place in that period (Lehto et al., 2008).

The Baby-Boomer Generation: This generation comprised of those individuals born between the years 1946 and 1964 is referred to as the "Baby Boomers" due to the 1 billion babies born during the "population explosion" years following the Second World War. The individuals born during this period are also called the children of the cold-war era (Ayhün, 2013).

The $\mathbf{Z}$ Generation: The $\mathrm{Z}$ generation is a generation that is devoid of complexes, nested with the technology, more individualistic, take pleasure in creativity and innovations, result-oriented, self-confident but dissatisfied. The fact that they have ample opportunities and the difficulties they have in postponing entertainment are the most important obstacles they have in becoming successful. They want to learn when they themselves wish to learn and under the conditions they themselves have decided on. They like creative activities, refuse passiveness, activate their long-term memories by games, creating stories and their dreams rather than memorization. Impersonation while learning something enables them to come up with their own examples (Yelkikalan et al., 2010). They are used to intensive message bombing coming from high technology use and information sources. Values of the $Z$ generation are individuality and realism. It is crucially important for the individuals in this generation to be a member of peer groups. Security is very important for them. They are selfassured, optimistic and know their responsibilities (Williams and Page, 2011). 
The $\mathbf{X}$ Generation: This generation is comprised of those individuals born between the years 1965 and 1979. This generation that follows the Baby Boomers generation and is also referred to as 'Baby Buster' is also called 'twenty something' and 'f-you generation' (Adigüzel et al., 2014). As they are able to adapt to the changing conditions, the $\mathrm{X}$ generation is regarded as abstemious, socialist, loyal and idealistic generation. The reason why the $\mathrm{X}$ generation is named as the transitional period comes from the fact that some significant changes and transformations at the global scale have begun to be experienced in those years (Senbir, 2004). It is not always possible to be able to communicate with the $\mathrm{X}$ generation. The traditional means of communication, especially the television are insufficient in attracting the attention of this generation. Cable television and the internet have had their impact over the consumers in this generation. It is important to provide opportunities to these consumers in terms of access to information and develop their purchasing behaviors. With regards to the process of communication, it is essential that they are asked for feedback and share information on a regular basis. The internet, e-mails, multimedia tools, word of mouth communication and social activities have significant effects over this generation (Williams and Page, 2011).

The Y Generation: The Y generation comprised of individuals born between the years 1980 and 1994 is also denoted by such concepts as the Millennium Generation, the Echo Boomers, the Why Generation, the Net Generation, the Biz Generation, the Dot Net and the Nexters. Unlike the previous generations, the individuals in this generation have the privilege of being born into the world where there is international solidarity and global connections. The individuals in this generation who have social, cultural and environmental awareness also have a strong sense of family, friends and loyalty to the social communities (Bucic et al., 2012).

The Y generation that differs from the other generations due to the conditions they were brought up and they grew up in a time period when technological opportunities such as computers and GSM technologies also developed (Senbir, 2004). Therefore, the basic characteristic of the $\mathrm{Y}$ generation is the fact that they are exposed to the technology that has both advantages and disadvantages with regards to cognitive, emotional and social consequences at an early age and frequently. Furthermore, the individuals in this generation have also followed the instant communication technologies, social networks and the rapid developments regarding the subject of globalization (Bolton et al., 2013). The main characteristics defining this particular generation are; they have ethnic diversity; they are global, independent and selfconfident; they are able to adapt themselves to changing situations; and they are multitaskers. From psychological perspective, the Y generation has a high sense of self, high level of self-admiration, and is in the center of external control. The individuals in this generation are tech-savvy, have a high potential for adaptation and learning oriented. The positive characteristics are; they are innovative, productive, flexible, open-minded, and have a high sense of responsibility. Characteristics such as being impatient, laidback, suspicious, disrespectful and outspoken are among the negative characteristics of this generation (Anantatmula and Shrivastav, 2012: 12).

The individuals in the $\mathrm{Y}$ generation that may wish to consume for the sake of publicizing their wealth and purchasing power as a symbol of social status have developed themselves by means of the financial support from their parents. The Y generation that has grown up in a wealthy family has more reasons and opportunities to 
spend money. With the developments in media tools and the internet, this generation is more consumption-oriented than the other generations. The Y Generation $\mathrm{Y}$ is also under the influence of reference groups. As a symbol of wealth and social status, they demand expensive goods and services. It is observed that the female consumers in the $\mathrm{Y}$ Generation are fond of luxury brands (Kim and Jang, 2014). The Y generation differs from the other generations due to the fact that they are more free-spirited and technophile (Yaşa and Bozyiğit, 2012).

\section{2. $X$ and $Y$ Generations' Use of Technology and the Internet}

Even though the $\mathrm{X}$ Generation is considered to be technology-oriented, the $\mathrm{Y}$ Generation is closely involved in the internet in their everyday lives. For the $\mathrm{Y}$ Generation, technology has an important place for them in every aspect of life (Behrstock-Sherratt and Coggshall, 2010; Simões and Gouveia, 2008). While the mature individuals of the $\mathrm{X}$ generation use computers to fulfill their duties, the individuals of the $\mathrm{Y}$ generation become online and offline on the computer without any problem. The youngsters of this generation want to communicate with others at any time and in any social context (Tan, 2012). Unlike the other generations, the traditional media tools such as television and radio may be insufficient in their appeal to the $Y$ generation. The most import way to appeal this generation is the internet (Marketing to Generation Y, 2010: 3). Especially the technologies related to social networks become an intrinsic part of the social life of this generation. The $\mathrm{Y}$ generation uses the latest technologies in order to expand the social networks and get in touch with their families and friends. Many members of this generation are already used to using laptop computers, mobile phones, instant messaging, e-mails and the internet in many aspects of their lives. This particular life style influences the consumption patterns of this generation (Simões and Gouveia, 2008). People of ages have come adapt the technology, but the Y Generation actually grew up with it. The Y generation uses the internet to obtain information about goods and make informed decisions about consumption. The Y Generation consumers are busy with following the online shopping sites, blogs and online sources to keep track of the comments made by the other costumers about the goods (Bilgihan, 2014).

The Y generation that is continually online in the digital medium is composed of individuals who are pioneers in the use of mobile communication tools, connected to the network, cooperative, very sociable and frequently eager to be connected to the social networks. The internet, Twitter, Facebook, YouTube, Google, MSN and instant messaging are the constant occupations of this generation. By using the Facebook, it is possible to manage groups and post their comments about the tagged/shared pictures. The first step of the social technologies for the Y generation is the e-mails (Islam et al., 2011). The $Y$ generation spends a lot of time in front of the computer; $70 \%$ of them, on the other hand, check their mobile phones every hour (Stein, 2013). Mobile phones are mostly used by the members of the Y generation to browse the net, send e-mails, play games, and listen to music and record videos (Zickuhr, 2011:2). It is clearly seen that mobile phones and computers though to be a luxury for the previous generations have come to be important tools that meet the needs of this generation. Homes of $80 \%$ of this generation have computers and half of them have internet access as well (Marketing to Generation Y, 2010).

While the $\mathrm{X}$ Generation has some similarities with regards to the ownership of the tools cited above, they prefer the desktop PCs in terms of computers. There are no 
significant differences between the generations with regards to reading e-books or tablet PC ownership (Zickuhr, 2011). The Y Generation is technologically at a more advanced level; they love enjoyment as well as shopping online. The male members of this generation use the internet 1.7 times more in comparison to the female members. Generally, this group had adopted technology well; although they are not influenced by the advertisements, they are encouraged by the shops (Sullivan and Heitmeyer, 2008). The fact that they are technologically at a more advanced level enables them to be more self-confident in online shopping (Nusair, et al., 2011: 834). Lester et al. (2006) found that more than $95 \%$ of students used the internet and more than $91 \%$ experienced online shopping.

The theoretical and empirical literature cited above is the basis for our proposition. Thus, the following hypothesis is proposed:

H1: There is a significant relationship between the generations and their internet experience.

\subsection{Consumers' Online Information Search Behavior}

The process of consumers' online information search is one of the stages of the decision to make purchases involving obtaining information from various sources and integrating them. Information searching process is divided into two parts as internal and external search. Internal search generally involves the use information that the consumer has obtained before from an external source and experienced himself/herself; and the external search, on the other hand, involves consumers' obtaining information from an external source (Klein and Ford, 2003: 31). When consumers are unsure about the goods and the internal information is at a low level, they resort to external sources. The depth, type of source, type risks and the personal factors of the search influence the search behavior of consumers (Barber et al., 2009: 416).

There are three basic theoretical movements in the consumer information search literature. The first one involves psychological/motivational approach; this approach integrates the variables such as the individual, class of goods, and the task. The second movement is the economic approach; this approach uses the cost-benefit framework in their efforts of information search. The third one is the approach of consumers' information processing; this approach focuses on individuals' limits of memory and cognitive information processing (Schmidt and Spreng, 1996: 247).

Information search on the internet is dealt with within the subject of external information search behavior (Zgódka, 2011). The fact that the internet is an important part of human's life necessitates the investigation of the internet users and their online information search behavior from many perspectives (Uçak and Al, 2000: 328). As Rezabakhsh et al. (2006: 12) pointed out, the internet influenced the consumer power from various perspectives. The internet makes it possible for the users to have access to online information at any time and at any place, enables the online communication networks to emerge and to be used, and allows the users to control the follow of information individually and independently. As online information search is the pioneer of online purchasing, understanding of consumers' online information search behavior plays an important role in the success of businesses (Kulviwat et al., 2004: 245) 
With regards to the subject of information search on the web, Choo et al. (2000) explicated that four search modes existed in the information search process. These modes are:

- Undirected Viewing: In this mode, the individual is exposed to the information without any clear need for information in his/her mind. Many and various information sources are used and a huge amount of information is scanned. One is easily distracted due to the abundance of information.

- Conditioned Viewing: In this mode, a predetermined subject or a specific type of information is viewed directly.

- Informal Search: In this mode, the individual actively searches for information in order to learn and understand a subject in depth. The reason why this mode is informal is that it is relatively limited and involves a non-structural effort.

- Formal Search: In this mode, the individual is involved in a pre-planned effort in order to obtain specific information or information types about a subject. The reason why this mode is formal is that it involves a pre-determined procedure or methodology. The search focuses on obtaining the detailed information.

Internet search is a combined activity that mainly happens during the online information search process. In this sense, information search strategies involve using keywords, using the search engines, using a subject directory and visiting the wellknown sites (Ho et al., 2012: 1471). According to Kumar et al. (2005), goods information search made via the search engines by the online consumers is made through the formal information search cited above.

Consumers carry out a cost analysis while choosing a search strategy. Consumers are involved in making the online search until the perceived marginal benefit of searching is equal to the perceived marginal cost. At this point, the internet has a significant impact over the both sides of the equation (Klein and Ford, 2003: 30). The internet today has become one of the main sources of information for many goods and/or services such as real estate, automobiles, travel, computers and equipment, books and recordings (Ratchford et al., 2001: 7).

The internet offers comprehensive and various kinds of information in an attempt to minimize the spending of time, effort and costs (Peterson and Merino, 2003: 105). The fact that the internet has become the main source of information has enabled the elimination of especially geographical borders and travel time, have instant access to goods in any part of the world and have access to information that is impossible or too expensive to obtain from different sources. (Ratchford et al., 2001: 13). Furthermore, factors such as the fact that the internet does not require any physical contact of the consumers with the sales personnel, and offers a freer environment to the consumers during the purchasing process, possess much more information (Jepsen, 2007: 21), low transaction costs, easy access to the prices and price information, purchasing of appropriate services (Bei et al., 2004) all have positive impacts over the use of the internet by the consumers for information search. For instance, the study carried out by Ward and Lee (2000) concluded that consumers obtained more information about the goods via the online search in comparison to the information obtained from the traditional mediums in the consumer markets. In a study done with 233 Danish internet users by Jepsen (2007), on the other hand, it was found that the internet was mostly used to obtain information before purchasing the goods. In their study in which they 
investigated the online information search behaviors of students, Kurulgan and Argan (2007), on the other hand, found that students mostly used the internet as a tool for information search $(85.6 \%)$ and e-mail $(82.2 \%)$. In his study in which 330 students studying at six different universities in Turkey participated, Okay (2010: 102) investigated the purposes of internet use of technical teacher candidates. The study concluded that $60.9 \%$ (with the frequency of $34.2 \%$ "often" and $26.7 \%$ "always") of the students used the internet for the purpose of information search and carry out online transactions. In their study in which they qualitatively examined the information search behavior of the students, Yalçınalp and Askar (2003) also found that the students who adopted purpose-oriented information search strategy used the purposeful and planned information search style and those students who adopted the data-oriented information search strategy mostly used un-purposeful information search style.

In online information search; the perceived benefit, perceived costs and searching skills of the individuals are the factors that motivate them for online search. The perceived benefits of online information search are positively related to the search activity. In the context of online information search, the ease of technology use, online search effectiveness and user satisfaction are the predecessor of the perceived benefits of information search process. The perceived cost of information search is another factor as well. These perceived costs include financial costs and time, mental, psychological and behavioral (physical) efforts needed during the searching process. Searching skills, on the other hand, is comprised of factors such as information, training and experience (Kulviwat et al., 2004).

When the relevant literature regarding the information search of the consumers during the purchasing process is examined, it is seen that most of the studies concentrated on demographic factors or sectorial variables. For instance, in their study, Saigal and Mann (2010) investigated the demographic factors and the intermediary role of time pressure on English and Indian consumers during the information search process. The study concluded that regarding the data of age factor, as the age of the consumers in both countries increased, the amount of information search decreased. In their study in which they examined the relationship between the attitude towards online shopping and the age, Sorce et al. (2005:130) categorized the participant into the study as those under the age of 30, those aged between 30 and 49 and those 50 and above. The study concluded that as far as only the age factor was concerned, the young consumers searched the goods online more, but did not make purchases at the same ratio. It was found that the older consumers, on the other hand, mostly purchased the goods they searched for. The young consumers agreed more in comparison to the old consumers that online shopping was easier.

Role of gender is another variable that is investigated in the information search of the consumers. For instance, Barber et al. (2009) investigated the gender differences in an information search study. In their study, they conceded that information sources were perceived differently in relation to depending on internal information and purchase confidence. Park et al. (2009), on the other hand, investigated the effects of gender and goods categories on online information search. When compared with males, they found that females tended to search more for various kinds of information including goods and use the customer assessments and assistant representatives. Bhatnagar and Ghose (2004: 221) pointed out that males made more searches on the internet in last one month in comparison to females and spent more time than women in every visit. In their study, 
Dittmar et al. (2004: 426), on the other hand, stated that males spend more money and more frequently than females; males were more ease-oriented and less motivated for social interaction; nevertheless, the number of female internet users was higher and those who did online shopping preferred to purchase online for the sake of saving time and money.

Consumers' online information search behaviors were investigated in terms of such different sectors as health (Cotten and Gupta, 2004; Diaz et al., 2002; Eysenbach and Köhler, 2002; Morahan-Martin; 2004), tourism (Fodness and Murray, 1997, 1999; Pan and Fesenmaier, 2006; Ho et al., 2012), finance (Ramaswani et al., 2000), and automobiles (Kiel and Layton, 1981; Klein and Ford, 2003). In one of those studies, in their qualitative study involving a focus group, observations and comprehensive interviews, Eysenbach and Köhler (2002) examined how consumers searched for and assessed health information on the internet. Their study concluded that the internet user successfully managed to find answers regarding health information to their questions in 5 minutes 42 seconds on average. While the participants in the focus group assessed the reliability of the web site they were supposed to search, they pointed out that they initially checked the source, the professional design, the scientific and formal language and ease of use of the web site. In their study involving literature review in which they examined how the internet users found, assessed and used the online health information, Morahan-Martin (2004) also pointed that the internet was an important source in finding health information; however, as the quality of online health information was mixed, serious concerns started to emerge in recent years. In the Morahan-Martin study, it was stated that the users who sought online health information usually used the search engines and mostly entered misspelled words in the search engines. This search does not usually go beyond the first page search. Moreover, both the searches and assessment skills of the internet users are limited in assessing the online health information. The internet users, for the most part, do not pay much attention to the reliability indicators. However, the information obtained as result of search has an impact over the healthrelated decision by the internet users, their friends and family members.

In the tourism sector, which is a knowledge-intensive sector, businesses also offer their goods to the market through various communication channels and establish customer relations. At this point, for tourists, the internet is the most effective tool used in search for and purchase of tourism-related goods and services. The internet is an important tool for information collection especially for tourist to obtain information about faraway places and carry out their holiday plans (Pan and Fesenmaier, 2006: 809810 ). In their study in which they investigated the tourism information search patterns of the web users, Ho et al. (2012) pointed out that the information search experience of the web users was composed of many factors such as previous information and search experience, online search strategies, information processing and recording, and barriers against online search.

Another area where consumers make intensive searches for online information is finance and banking sector. For instance, in their study in which they investigated the markers of online channel usage in the purchasing of financial goods and services. Ramaswami et al. (2000) found that consumers used these channels not only for online purchasing, but also search for information as well. Furthermore, it was also found that the consumers who used online channels for information search had a greater tendency to use these channels to carry out these financial transactions. 
In their study in which they examined information search of the consumers during the process of purchasing automobile, Klein and Ford (2003) pointed out that consumer used online search as a substitution for traditional searches. Even together with the rapid development of the internet, as the experience of internet increased, more experienced internet users began to carry out most of their searching activities online. In their study in which they investigated the dimension of information search behavior of Australian consumers who just bought a new car, Kiel and Layton (1981), on the other hand, consumers' information search behavior was comprised of the components of time dimension, retail search, media search, interpersonal search, and deliberative search.

Online shopping motives of consumers are various; they can classified as generally goal-oriented (convenience, obtaining a good deal) and enjoyment as a way of obtaining new information about a field of interest. Furthermore, online shopping is also positively affected by the perception of informativeness and convenience in making a good choice (Sorce et al., 2005). Consumers' perception of risks and time pressure also has an impact over the information search behavior (Laroche, et al., 2000: 502). Perceived high risk negatively influences especially the choice of the shopping place and the online shopping (Sorce et al., 2005: 124; Barnes et al., 2007: 75).

Given the comprehensive literature review cited above, it is clearly seen that the subjects of consumers' information search and online information search have been mostly investigated in terms of demographics and sectors; nevertheless, there are no generation-based studies regarding online information and opinion behaviors. At this point, the second hypothesis is proposed here in attempt to analyze generation differences with regard to consumers' preferences for online information and opinion search behavior. The statements comprising this particular purpose are illustrated in Table 4, and the second hypothesis is as follows:

H2: The online information and opinion search behaviors are different in the $\mathrm{X}$ and $\mathrm{Y}$ generations of consumers.

\section{Methodology}

\subsection{Purpose}

The purpose of this paper is to investigate whether there exist differences in online information and opinion search behaviors according to the $\mathrm{X}$ and $\mathrm{Y}$ generation of the respondents as consumers.

\subsection{Sampling}

There is no listing of $\mathrm{X}$ and $\mathrm{Y}$ generations of consumers that can be used for sampling in Turkey. For the sampling procedure, convenience sampling was used. Therefore, we decided to include respondents in our research from the $\mathrm{X}$ and $\mathrm{Y}$ generations using the internet and doing online shopping in the city of Bursa in Turkey.

\subsection{Data Collection and Questionnaire}

Face to face questionnaire was used to collect the data. A questionnaire adopted from the previous research (Goldsmith and Horowitz, 2006) was used to measure consumers' online information and opinion search behaviors. The questionnaire was comprised of five multiple-choice and 32 Likert-type items. Respondents were asked to specify how long (less than one year, 1-3 years, 4-5 years, 6-7 years, 8 years and over) (Teo, 2002) they had been using the internet for. The questionnaire also elicited respondents' biographical data regarding age, gender and education. Online information 
and opinion search behaviors were rated by respondents on a 5-point Likert scale (strongly disagree $=1$; strongly agree $=5$ ). Prior to the final data collection, the questionnaire was pre-tested with 30 respondents to evaluate how well the questionnaire was understood. None of the questions needed simplification. The questionnaire was conducted during the period of April-June 2016.

\subsection{Data Analysis}

The data were analyzed by descriptive statistics (frequencies and means). ChiSquare analysis was used to identify the relationship with the internet experience and generation of consumers. Exploratory and confirmatory factor analyses were conducted to identify the main groups of online information and opinion search behaviors. Independent-sample t-tests were performed in order to analyze generation differences in preferences towards online information and opinion search behaviors. For the statistical analyses, SPSS 23 and AMOS 23 were used. The level of significance was set at 0.05 . Further analysis on the scales' reliability was conducted by calculating Cronbach's alpha. When first calculated, the value of Cronbach's alpha was 0.852 . Items that can be extracted to increase the reliability of the scale have been examined. As a result of this evaluation, when seven items were dropped from the scale, the value of Cronbach's alpha increased to 0.889 as overall indicating good reliability.

\section{Results}

\subsection{Participants' Characteristics}

The study carried out in Bursa is composed of a total of 515 participants 252 of whom were males and 263 females using the internet and doing online shopping (187 participants from $\mathrm{X}$ generation, 328 from $\mathrm{Y}$ generation). When they are examined from the perspective of generations, the $\mathrm{X}$ generation was composed of 102 males and 85 females; and the Y generation 150 males and 178 females. Examined the education status of the participants, the number of those with elementary school education was 38 , high school education 84, university degree 368 and those with post-graduate education 25 participants took part in the study. When the education status of the participants are examined with regards to the participating generations, on the other hand, it was found that only all those with elementary education were comprised of the $\mathrm{X}$ generation (38 individuals), only 76 of the those with high school education were from the $\mathrm{X}$ generation and 8 from the Y generation. It was also found that 68 participants of those with university degree were from the $X$ generation and 300 from the $Y$ generation. 5 of the individuals from the $\mathrm{X}$ generation and 20 from the $\mathrm{Y}$ generation had post-graduate education.

\subsection{Measures}

\subsubsection{Internet Experience by Generation of Consumers}

Results of the Chi-Square tests for 2-sided sig. value indicate that there is a significant relationship between generation of consumers and their internet experiences $(\chi 2=32.03, p=0.00, p<0.05)$. In other words, $\mathrm{H} 1$ is supported. Members of the $\mathrm{Y}$ generation use the internet for longer than $\mathrm{X}$ generation, which is an indicator of internet experience (see Table 2). 
Table 2. Internet Experience by Generation of Consumers

\begin{tabular}{|l|c|c|c|c|c|c|c|}
\hline & & Less than 1 year & 1-3 Years & 3-5 Years & 5-7 Years & 7 Year and over & Total \\
\hline \multirow{2}{*}{ X Generation } & $\mathbf{n}$ & 20 & 44 & 42 & 28 & 53 & 187 \\
\cline { 2 - 9 } & $\mathbf{\%}$ & 0,106 & 0,235 & 0,224 & 0,149 & 0,283 & 100 \\
\hline \multirow{2}{*}{ Y Generation } & $\mathbf{n}$ & 5 & 64 & 107 & 73 & 78 & 328 \\
\cline { 2 - 8 } & $\mathbf{\%}$ & 0,015 & 0,195 & 0,326 & 0,222 & 0,237 & 100 \\
\hline \multicolumn{7}{|c|}{ Chi- Square Tests } \\
\hline
\end{tabular}

\subsubsection{Online Information and Opinion Search Behaviors}

One of the fundamental purposes of this research is to establish which online information and opinion search behaviors are preferred by the $\mathrm{X}$ and $\mathrm{Y}$ generations of consumers. For this purpose, a varimax rotated exploratory factor analysis was carried by using the principle components technique. Before the exploratory factor analysis, the Cronbach's Alfa value of the scale was examined and it was seen that no variable existed within the scale that reduced the reliability. The Kaiser-Meyer-Olkin (KMO) measurement regarding the proficiency of sample was 0.875 . This value is within the acceptable limits. The Barlett Sphericity Test results demonstrate that factor analysis can be used for these scale questions $(\chi 2=5434.859 ; \mathrm{p}=0.00)$. The varimax rotated principle components technique was used in order to test the validity of theory-based model. The factor analysis demonstrated that a consistent structure in which 25 variables were collected under 6 factors. The exploratory factor analysis results showed that factor loadings were between 0,50 and 0,85 . 6 factors (comprising nearly $63 \%$ of the total variation) whose eigenvalue were greater than 1 were found and these factors (according to their total variances) were named as price-value perception, avoiding risks, instant information and opinion acquisition, convenience, enjoyment and acquaintance/friend effect. The factors, the characteristics of these factors, the subvariables included in each factor and factor loadings are all illustrated in Table 3 . The 8 factors (Perceived risk, influence of others, price consciousness, ease of use, accidentally, it's cool, to get information and saw on TV) in the original measure performed by Goldsmith and Horowitz (2006) are similar to the 6 factors in our study. However, the 6 factors in our study were named different from the factors in the original measure taking into account the items in the factors and the weight of the factor loadings. The factors of "to get information" and "saw on TV" were not found as a separate factor in our study. The differences are due to scale used in a different culture and items dropped from the scale. 
Table 3: Factors and factor loadings

\begin{tabular}{|c|c|c|c|c|c|c|}
\hline \multirow[b]{2}{*}{ Online information and opinion search behaviors } & \multicolumn{6}{|c|}{ Factors } \\
\hline & 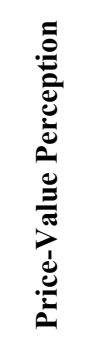 & 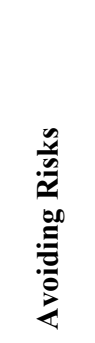 & 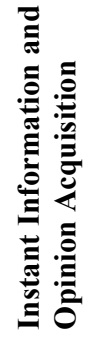 & 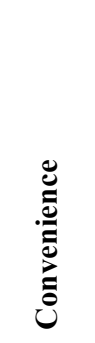 & 氞 & 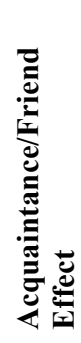 \\
\hline $\begin{array}{l}\text { 1. Since a bad purchasing decision is likely to minimize } \\
\text { my purchasing possibility, I do information/opinion } \\
\text { search on the internet. }\end{array}$ & & 0.680 & & & & \\
\hline $\begin{array}{l}\text { 2. As I do not want to regret it due to my purchasing } \\
\text { decision, I do information/opinion search on the } \\
\text { internet. }\end{array}$ & & 0.820 & & & & \\
\hline $\begin{array}{l}\text { 3. Since it helps me to avoid a risky purchasing decision, } \\
\text { I do information/opinion search on the internet. }\end{array}$ & & 0.782 & & & & \\
\hline $\begin{array}{l}\text { 4. In order to obtain information about the goods, I wish } \\
\text { to purchase from people who have already purchased } \\
\text { it, I do information/opinion search on the internet. }\end{array}$ & & 0.549 & & & & \\
\hline $\begin{array}{l}\text { 5. Since obtaining information from the internet } \\
\text { minimizes the risk of making bad choices, I do } \\
\text { information/opinion search on the internet. }\end{array}$ & & 0.726 & & & & \\
\hline $\begin{array}{l}\text { 6. In order to make sure that the goods are worth } \\
\text { purchasing, I do information/opinion search on the } \\
\text { internet. }\end{array}$ & & 0.508 & & & & \\
\hline $\begin{array}{l}\text { 7. Since it helps me to find the cheapest goods, I do } \\
\text { information/opinion search on the internet. }\end{array}$ & 0.714 & & & & & \\
\hline $\begin{array}{l}\text { 8. In order to compare the prices of the goods of my } \\
\text { interest, I do information/opinion search on the } \\
\text { internet. }\end{array}$ & 0.662 & & & & & \\
\hline $\begin{array}{l}\text { 9. In order to get the best value for money, I do } \\
\text { information/opinion search on the internet. }\end{array}$ & 0.714 & & & & & \\
\hline $\begin{array}{l}\text { 10. Since it helps me to find goods offering best value for } \\
\text { money, I do information/opinion search on the internet. }\end{array}$ & 0.748 & & & & & \\
\hline $\begin{array}{l}\text { 11.In order to get the best quality goods available in the } \\
\text { market, I do information/opinion search on the internet. }\end{array}$ & 0.703 & & & & & \\
\hline $\begin{array}{l}\text { 12. Since it helps me to find and compare choices of } \\
\text { highest quality goods, I do information/opinion search } \\
\text { on the internet. }\end{array}$ & 0.626 & & & & & \\
\hline $\begin{array}{l}\text { 13. As I am able to easily search for the goods of my } \\
\text { interest regarding home, work and school, I do } \\
\text { information/opinion search on the internet. }\end{array}$ & & & & 0.622 & & \\
\hline $\begin{array}{l}\text { 14. Since using the internet (being online) is usually the } \\
\text { easiest way of obtaining information, I do } \\
\text { information/opinion search on the internet. }\end{array}$ & & & & 0.589 & & \\
\hline $\begin{array}{l}\text { 15. When I come across a subject of self-interest while } \\
\text { reading my e-mails, I do information/opinion search on } \\
\text { the internet. }\end{array}$ & & & 0.826 & & & \\
\hline $\begin{array}{l}\text { 16. When I come across a subject of interest while surfing } \\
\text { the net, I do information/opinion search on the internet. }\end{array}$ & & & 0.798 & & & \\
\hline $\begin{array}{l}\text { 17. While using the instant messaging, (such as Windows } \\
\text { Live Messenger, Yahoo Messenger) when information } \\
\text { of self-interest is sent to me, I do information/opinion } \\
\text { search on the internet. }\end{array}$ & & & 0.710 & & & \\
\hline $\begin{array}{l}\text { 18. When I am online and when information of self- } \\
\text { interest is sent to me, I do information/opinion search } \\
\text { on the internet. }\end{array}$ & & & 0.781 & & & \\
\hline
\end{tabular}




\begin{tabular}{|c|c|c|c|c|c|c|}
\hline $\begin{array}{l}\text { 19. When I see the pictures of goods on the web pages or } \\
\text { e-mails, I do information/opinion search on the } \\
\text { internet. }\end{array}$ & & & & & 0.653 & \\
\hline $\begin{array}{l}\text { 20. Since obtaining information on the internet is fun, I do } \\
\text { information/opinion search on the internet. }\end{array}$ & & & & & 0.788 & \\
\hline $\begin{array}{l}\text { 21. In order to obtain information about the goods of self- } \\
\text { interest from the people with positive and negative } \\
\text { opinions, I do information/opinion search on the } \\
\text { internet. }\end{array}$ & & & & & 0.618 & \\
\hline $\begin{array}{l}\text { 22. Since my friends successfully search for information } \\
\text { on the internet, I do information/opinion search on the } \\
\text { internet. }\end{array}$ & & & & & & 0.826 \\
\hline $\begin{array}{l}\text { 23. Since other people think that searching for information } \\
\text { on the internet is useful, I do information/opinion } \\
\text { search on the internet. }\end{array}$ & & & & & & 0.859 \\
\hline $\begin{array}{l}\text { 24. Since I am able to obtain information on the internet } \\
\text { with little effort, I do information/opinion search on the } \\
\text { internet. }\end{array}$ & & & & 0.746 & & \\
\hline $\begin{array}{l}\text { 25. Since the information I need is easy to access for me, I } \\
\text { do information/opinion search on the internet. }\end{array}$ & & & & 0.797 & & \\
\hline Eigenvalues & 7.585 & 2.549 & 1.668 & 1.413 & 1.248 & 1.186 \\
\hline Variation & 30.341 & 10.199 & 6.673 & 5.655 & 4.995 & 4.746 \\
\hline
\end{tabular}

When the factors obtained as a result of exploratory factor analysis and the subvariables related to these factors are examined, it is seen that price-value perception accommodated nearly $30 \%$ of the total variation. This factor had 6 sub variables, and of these factors, the factor that had the highest factor loading had the variable "Since it helps me to find goods offering best value for money, I do information/opinion search on the internet" (Factor loading = 0.748). The other sub variables of "In order to get the best value for money, I do information/opinion search on the internet" (Factor loading = 0.714) and "Since it helps me to find the cheapest goods, I do information/opinion search on the internet" (Factor loading $=0.714$ ) were those that had the highest share. The factor of avoiding risks was composed of $6 \mathrm{sub}$ variables and explicated nearly $10 \%$ of the total variation. The sub variables of "As I do not want to regret it due to my purchasing decision, I do information/opinion search on the internet" (Factor loading = 0.820) and "Since it helps me to avoid a risky purchasing decision, I do information/opinion search on the internet" (Factor loading $=0.782$ ) were the ones that had the highest share in this factor. The instant information and opinion acquisition factor was composed of the sub variables of "When I come across a subject of selfinterest while reading my e-mails, I do information/opinion search on the internet"(Factor loading $=0.826$ ) and "When I come across a subject of interest while surfing the net, I do information/opinion search on the internet" (Factor loading = 0.798) had the highest shares in this factor and this factor explicated nearly $7 \%$ of the total variation. The factor of convenience explicated nearly $5.7 \%$ of the total variation and was comprised of four sub variations. "Since the information I need is easy to access for me, I do information/opinion search on the internet" (Factor loading $=0.797$ ) and "Since I am able to obtain information on the internet with little effort, I do information/opinion search on the internet" (factor loading $=0.746$ ) sub variables had the highest shares in this factor. The enjoyment factor was composed of the sub variables of "Since obtaining information on the internet is fun, I do information/opinion search on the internet" (Factor loading $=0.788$ ) "When I see the pictures of goods on the web pages or e-mails, I do information/opinion search on the internet " (Factor loading $=0.653$ ) and "In order to obtain information about the goods of self-interest from the people with positive and negative opinions, I do 
information/opinion search on the internet" (Factor loading $=0.618$ ), and explicated nearly $5 \%$ of total variation. The acquaintance/friend effect factor explicated nearly $4.8 \%$ of the total variation together with the sub variables of "Since other people think that searching for information on the internet is useful, I do information/opinion search on the internet" (Factor loading $=0.859$ ) and "Since my friends successfully search for information on the internet, I do information/opinion search on the internet" (Factor loading $=0.826$ ).

The structure coherence of the scale used for the analysis was also tested by confirmatory factor analyses. The six-factor confirmatory factor analysis was performed. We used the confirmatory factor analysis in order to simultaneously evaluate the relations of each item with the factor representing the construct they were supposed to measure and to determine whether these six factors together represent a valid structure. Confirmatory factor analysis was conducted to determine the validity of the scale when a scale was applied in a different culture.

In the study, the values of skewness and kurtosis of the data were examined and it was seen that the data showed normal distribution. The skewness and kurtosis values of the factors were as follows; Price-value perception (skewness $=-.759$; kurtosis $=.380$ ), avoiding risks (skewness $=-.770 ;$ kurtosis $=.527$ ), instant information and opinion acquisition (skewness $=-.778$; kurtosis $=.662$ ), convenience (skewness $=-.618$; kurtosis $=$ .061 ), enjoyment (skewness $=-.322$; kurtosis $=-.161$ ), acquaintance/friend effect (skewness $=-.388$; kurtosis $=-.427$ ). The values of skewness and kurtosis between the values of $-1,5$ and $+1,5$ were within the required limits (Tabachnick and Fidel, 2012). As a result of the analysis carried out in AMOS 23 program, it was seen that some modifications have to be made. It was found that the coherence indexes of the scale before modification were $\chi 2 / \mathrm{df}=3,60$, root mean square error of approximation $($ RMSEA $)=0.07$, root mean square residual $($ RMR $)=0.06$, goodness of fit index $(\mathrm{GFI})=$ 0.87 , comparative fit index $(\mathrm{CFI})=0.87, \mathrm{p}=0.001$. It was found that the coherence indexes of the scale after modification were $\chi^{2 / \mathrm{df}}=2.96$, root mean square error of approximation $(\mathrm{RMSEA})=0.06$, root mean square residual $(\mathrm{RMR})=0.06$, goodness of fit index $(\mathrm{GFI})=0.90$, comparative fit index $(\mathrm{CFI})=0.90, \mathrm{p}=0.001$. In the literature, the accepted values of these indices are $\chi 2 / \mathrm{df} \leq 3$; GFI $>.90$; CFI $>.90 ; 0.05<$ RMSEA $<$ 0.08 (Baumgartner and Homburg, 1996; Iacobucci, 2010; Weston and Gore, 2006). The results of the confirmatory factor analysis show a good fit.

\subsubsection{The relationship between online information and opinion search behaviors and generations}

In this study, it was examined whether there were significant differences in online information and opinion search behaviors based on generation; a t-test analysis was used to reveal in which online information and opinion search behaviors differences were found among the behaviors analyzed. The means of the behaviors likely to be preferred in online information and opinion search behaviors based on generation used in the t-test are illustrated in Table 4. Looking at Table 4, the $\mathrm{Y}$ generation, when compared to the $\mathrm{X}$ generation, generally preferred " In order to compare the prices of the goods of my interest, I do information/opinion search on the internet", " Since using the internet (being online) is usually the easiest way of obtaining information, I do information/opinion search on the internet", "Since the information I need is easy to access for me, I do information/opinion search on the internet", "While using the instant messaging, (such as Windows Live Messenger, Yahoo Messenger) when information of 
self-interest is sent to me, I do information/opinion search on the internet", "When I come across a subject of self-interest while reading my e-mails, I do information/opinion search on the internet" and "When I come across a subject of interest while surfing the net, I do information/opinion search on the internet" more; the $\mathrm{X}$ generation preferred "Since it helps me to avoid a risky purchasing decision, I do information/opinion search on the internet" and "In order to obtain information about the goods I wish to purchase from people who have already purchased it, I do information/opinion search on the internet " more. When the averages of the responses obtained are generally examined, it is clearly seen that the online information and opinion search behavior averages of the $\mathrm{Y}$ generation are higher in comparison to the $\mathrm{X}$ generation.

Table 4. Online Information and Opinion Search Behaviors by Generation of Consumers

\begin{tabular}{|c|c|c|}
\hline \multirow{2}{*}{$\begin{array}{l}\text { Online Information and Opinion Search Behaviors by } X \text { and } Y \text { Generation of } \\
\text { Consumers }\end{array}$} & \multicolumn{2}{|c|}{ Means $^{a}$} \\
\hline & \begin{tabular}{c|c|} 
\\
Generation \\
\end{tabular} & $\begin{array}{c}\text { Y } \\
\text { Generation } \\
\end{array}$ \\
\hline $\begin{array}{l}\text { 1. Since a bad purchasing decision is likely to minimize my purchasing possibility, I } \\
\text { do information/opinion search on the internet. }\end{array}$ & 3.62 & 3.91 \\
\hline $\begin{array}{l}\text { 2. As I do not want to regret it due to my purchasing decision, I do } \\
\text { information/opinion search on the internet. }\end{array}$ & 3.65 & 3.76 \\
\hline $\begin{array}{l}\text { 3. Since it helps me to avoid a risky purchasing decision, I do information/opinion } \\
\text { search on the internet. }\end{array}$ & 3.71 & 3.68 \\
\hline $\begin{array}{l}\text { 4. In order to obtain information about the goods, I wish to purchase from people } \\
\text { who have already purchased it, I do information/opinion search on the internet. }\end{array}$ & 3.88 & 3.71 \\
\hline $\begin{array}{l}\text { 5. Since obtaining information from the internet minimizes the risk of making bad } \\
\text { choices, I do information/opinion search on the internet. }\end{array}$ & 3.61 & 3.80 \\
\hline $\begin{array}{l}\text { 6. In order to make sure that the goods are worth purchasing, I do } \\
\text { information/opinion search on the internet. }\end{array}$ & 3.42 & 3.78 \\
\hline $\begin{array}{l}\text { 7. Since it helps me to find the cheapest goods, I do information/opinion search on } \\
\text { the internet. }\end{array}$ & 3.76 & 3.76 \\
\hline $\begin{array}{l}\text { 8. In order to compare the prices of the goods of my interest, I do } \\
\text { information/opinion search on the internet. }\end{array}$ & 3.81 & 4.07 \\
\hline $\begin{array}{l}\text { 9. In order to get the best value for money, I do information/opinion search on the } \\
\text { internet. }\end{array}$ & 3.63 & 3.89 \\
\hline $\begin{array}{l}\text { 10. Since it helps me to find goods offering best value for money, I do } \\
\text { information/opinion search on the internet. }\end{array}$ & 3.71 & 3.84 \\
\hline $\begin{array}{l}\text { 11.In order to get the best quality goods available in the market, I do } \\
\text { information/opinion search on the internet. }\end{array}$ & 3.43 & 3.77 \\
\hline $\begin{array}{l}\text { 12. Since it helps me to find and compare choices of highest quality goods, I do } \\
\text { information/opinion search on the internet. }\end{array}$ & 3.73 & 3.85 \\
\hline $\begin{array}{l}\text { 13. As I am able to easily search for the goods of my interest regarding home, work } \\
\text { and school, I do information/opinion search on the internet. }\end{array}$ & 3.95 & 3.97 \\
\hline $\begin{array}{l}\text { 14. Since using the internet (being online) is usually the easiest way of obtaining } \\
\text { information, I do information/opinion search on the internet. }\end{array}$ & 3.54 & 4.01 \\
\hline $\begin{array}{l}\text { 15. When I come across a subject of self-interest while reading my e-mails, I do } \\
\text { information/opinion search on the internet. }\end{array}$ & 3.04 & 3.82 \\
\hline $\begin{array}{l}\text { 16. When I come across a subject of interest while surfing the net, I do } \\
\text { information/opinion search on the internet. }\end{array}$ & 3.30 & 3.81 \\
\hline $\begin{array}{l}\text { 17. While using the instant messaging, (such as Windows Live Messenger, Yahoo } \\
\text { Messenger) when information of self-interest is sent to me, I do } \\
\text { information/opinion search on the internet. }\end{array}$ & 2.95 & 3.63 \\
\hline $\begin{array}{l}\text { 18. When I am online and when information of self-interest is sent to me, I do } \\
\text { information/opinion search on the internet. }\end{array}$ & 3.41 & 3.77 \\
\hline $\begin{array}{l}\text { 19. When I see the pictures of goods on the web pages or e-mails, I do } \\
\text { information/opinion search on the internet. }\end{array}$ & 3.03 & 3.14 \\
\hline $\begin{array}{l}\text { 20. Since obtaining information on the internet is fun, I do information/opinion } \\
\text { search on the internet. }\end{array}$ & 3.29 & 3.28 \\
\hline
\end{tabular}




\begin{tabular}{|l|c|c|}
\hline $\begin{array}{l}\text { 21.In order to obtain information about the goods of self-interest from the people } \\
\text { with positive and negative opinions, I do information/opinion search on the } \\
\text { internet. }\end{array}$ & 3.67 & 3.80 \\
\hline $\begin{array}{l}\text { 22. Since my friends successfully search for information on the internet, I do } \\
\text { information/opinion search on the internet. }\end{array}$ & 3.14 & 3.23 \\
\hline $\begin{array}{l}\text { 23. Since other people think that searching for information on the internet is useful, I } \\
\text { do information/opinion search on the internet. }\end{array}$ & 3.29 & 3.27 \\
\hline $\begin{array}{l}\text { 24.Since I am able to obtain information on the internet with little effort, I do } \\
\text { information/opinion search on the internet. }\end{array}$ & 3.63 & 3.90 \\
\hline $\begin{array}{l}\text { 25.Since the information I need is easy to access for me, I do information/opinion } \\
\text { search on the internet. }\end{array}$ & 3.97 & 4.11 \\
\hline
\end{tabular}

${ }^{a}$ 1. Strongly disagree, 2. Disagree, 3. Neutral, 4. Agree, 5. Strongly agree

When the t-test analysis was applied to the hypothesis formed, the three behaviors (factors) in online information and opinion search displayed differences in terms of generation. Looking at Table 5, since 2-sided sig. values of these, three features were $<0.05$, the $\mathrm{H} 2$ hypothesis was accepted. In other words, no significant generation-based differences amongst consumers were found in the other behaviors apart from those of three.

Table 5. T-Test Results about Online Information and Opinion Search Behaviors by $X$ and $Y$ Generation of Consumers

\begin{tabular}{|c|c|c|c|c|c|c|c|}
\hline \multirow{2}{*}{$\begin{array}{l}\text { Online Information and } \\
\text { Opinion Search } \\
\text { Behaviors }\end{array}$} & \multirow[t]{2}{*}{$\mathbf{t}$} & \multirow[t]{2}{*}{ df } & \multirow[t]{2}{*}{$\begin{array}{c}\text { Sig. } \\
\text { (2-tailed) }\end{array}$} & \multirow[t]{2}{*}{$\begin{array}{c}\text { Mean } \\
\text { Difference }\end{array}$} & \multirow[t]{2}{*}{$\begin{array}{l}\text { Std. Error } \\
\text { Difference }\end{array}$} & \multicolumn{2}{|c|}{$\begin{array}{l}95 \% \text { Confidence } \\
\text { Interval of the } \\
\text { difference }\end{array}$} \\
\hline & & & & & & Lower & Upper \\
\hline Price-Value Perception & -1.68 & 513 & 0.093 & -0.12 & 0.07 & -0.27 & 0.02 \\
\hline Avoiding Risks & -2.63 & 513 & 0.009 & -0.19 & 0.07 & -0.33 & -0.05 \\
\hline $\begin{array}{l}\text { Instant Information and } \\
\text { Opinion Acquisition }\end{array}$ & -3.27 & 513 & 0.001 & -0.23 & 0.07 & -0.36 & -0.09 \\
\hline Convenience & -7.16 & 513 & 0.000 & -0.59 & 0.08 & -0.75 & -0.42 \\
\hline Enjoyment & -0.95 & 513 & 0.342 & -0.07 & 0.08 & -0.22 & 0.08 \\
\hline Acquaintance/Friend Effect & -0.35 & 513 & 0.723 & -0.03 & 0.09 & -0.21 & 0.15 \\
\hline
\end{tabular}

\section{Conclusion}

Customer segmentation is a quite important marketing practice in the success of businesses. It is because understanding the consumers' behaviors in different consumer segments makes significant contributions to development of strategies that will make it possible to reach out to the consumers in the targeted segment (Barnes et al., 2007: 72). Therefore, knowing the information search behaviors of consumers also has a significant role to play in the development of appropriate strategies in the relevant segment. (Laroche et al., 2004: 62). In this sense, knowing the behaviors of generations with different characteristics and consumer behaviors is crucially important for the marketing strategies and practices to be developed by the marketing managers.

In the present study, it was examined whether there were differences in online information and opinion search behaviors of the $\mathrm{X}$ and $\mathrm{Y}$ generations; and if there were, which factors were responsible for these differences. In the study, first of all, the relationship between the generations that the consumers belonged to and their experiences of internet use was investigated. As a result of our analyses, it was found that a statistically significant difference existed between the $\mathrm{X}$ and $\mathrm{Y}$ generations with regards to their experiences of internet use. When the data were analyzed, it was seen that Y generation's experiences of internet use was greater in comparison to those of $\mathrm{X}$ generation. This particular result is compatible with the information made available in 
the studies (Behrstock-Sherratt and Coggshall, 2010; Simões and Gouveia, 2008) in the relevant literature that the $\mathrm{Y}$ generation was more involved in the internet in their daily lives than the $\mathrm{X}$ generation. The experience of internet use is related with consumers' information search behaviors. For instance, according to the study carried out by Ward and Lee (2000), it was found that as the individuals' experiences of internet use increased, they searched for alternative information sources more and relied on brand names less. According to Darley et al.'s study, (2010), on the other hand, search behavior was influenced by individuals' internet use (experience) and interaction with the internet. Darley et al. (2010) recommended that in order to comprehend this interaction, psychological, socio-cultural and environmental factors should be introduced. In the present study, factors such as interest, type of goods (for instance experience, research concrete-abstract, simple-complex and high-low risk), personality (taking risks, cognitive risk), obtaining information, processing information and belief systems were dealt with as important moderators.

Since consumers of the Y generation use the internet, social media and mobile phones much more, the internet in general is defined as the media of young people. In this sense, the $\mathrm{Y}$ consumers who are the young consumers of today are in the early adopters segment of online shopping (Sorce et al., 2005: 122). Therefore, electronic commerce practices such as offer of online shopping opportunities on the online sites and news bulletins and sale advertisements communicated via e-mails are effective in reaching out the Y generation (Ng'ang'a, 2012). Therefore, if the marketing managers wish to successfully reach out this segment of the market, they should emphasize the issues such as transparent business approach and online access (Marketing to Generation Y, 2010).

In the present study, the scale questions regarding the online information and opinion search behavior of consumers were initially subjected to factor analysis. As a result of the analysis, the online information and opinion search behavior of consumers were collected under 6 factors. Therese factors were called; price-value perception, avoiding risks, instant information and opinion acquisition, convenience, enjoyment and acquaintance/friend effect. All these 6 factors obtained are compatible with the results of the study carried out by Goldsmith and Horowitz (2006). It was investigated by the ttest analysis whether the online information and opinion search behavior of the consumers in the $\mathrm{X}$ and $\mathrm{Y}$ generations differed. As a result of the analyses, it was concluded that the factors of avoiding risks, instant information and opinion acquisition and convenience were statistically different based on generations. When the averages of the $\mathrm{X}$ and $\mathrm{Y}$ generations regarding these factors are examined, it is seen that with regards to the three factors, the $\mathrm{Y}$ generation, in comparison to the $\mathrm{X}$ generation, did more search to avoid risks, were more inclined for instant information and opinion acquisition and found online information search easier. This particular result obtained in relation to avoiding risks is similar to those of previous studies done on this subject. For instance, in their study, Forsythe and Shi (2003) found that those who did online shopping perceived various in internet shopping. Similarly, in their study in which they dealt with convenience and internet shopping behavior, Bhatnagar et al. (2000) concluded that the convenience perceived by the consumer towards internet shopping had a positive impact over the online purchasing behavior of consumers. The risks affecting the internet shopping behavior in Bhatnagar and friends' study were the risk of goods category and financial risk. The study concluded that both risks in general diminished consumers' online purchasing possibility. Depending on the significance of 
the purchasing decision, consumers may use personal and non-personal sources and their own experiences to minimize the risks (Barber et al., 2009). This particular result obtained in this research is the most important finding that should be considered by the marketing managers especially if the consumer segment of the Y generation is targeted. As it was also pointed out by Bei et al. (2004), the perceived convenience, perceived ease of use and the use of online information sources is positively related with online information use. Therefore, in addition to offering more information over the internet, the marketing managers should also provide more opportunities where the consumers have discussions and share their experiences. Moreover, considering the perceived convenience and usefulness factors, the web sites should be designed in a user-friendly manner. Besides, the marketing managers should also consider the traditional sources of information, and take the online information into consideration together with the other information searched by the consumers. The subjects of technology and trust are also related with online consumer behaviors. For instance, in their study in which they investigated consumers' intentions to purchase goods from online shops from a the technology and trust-oriented perspective, Heijden et al. (2003) pointed out that trustantecedent was the perceived risk and technology-antecedent was ease of use, and found that these factors had a direct impact over consumers' online shopping behavior. In their study in which they investigated the factors affecting consumers' intentions towards online shopping, Chiang and Dholakia (2003) found that the convenience factor positively affected consumers' intentions towards online shopping. Since the consumers perceive offline shopping to be inconvenient, they are likely to turn to online shopping. In our study, the differences regarding the factors of instant information and opinion acquisition and convenience between the generations have similarities with the previous studies cited above and the results of the Ekici and Uçak (2012). In their study in which they investigated the internet search behavior of elementary school pupils, Ekici and Uçak (2012) also pointed out that elementary school pupils used the internet primarily to access online information and used it to do intensively. Furthermore, it was found in this study that the elementary school pupils perceived the internet as a medium where current, easily-accessible and all kind of information was available.

The results of this study regarding whether consumers" online information and opinion search differed based on $\mathrm{X}$ and $\mathrm{Y}$ generations is significant since there is a gap in the relevant literature about it and this study aims to fill in this gap. The closest studies to this subject are those related to the age of the consumers. For instance, in their study in which they examined the relationship between the attitude towards online shopping and age Sorce et al. (2005:131) pointed out that different marketing approaches should be implemented for the different consumer age segments. Accordingly, older consumers should be initially directed towards obtaining online information; the younger consumers, on the other hand, should be directed to make online purchases (Sorce et al., 2005: 131). In their study in which they investigated the perceived benefits of online shopping and consumer characteristics, Dholakia and Uusitalo (2002) found that the younger consumers in comparison to older consumers had motives towards more hedonic and utilitarian benefits for online shopping. The researchers should also deal with the social-cultural changes to see whether differences in the age factor considered as an important for traditional market segmentation stemmed from the differences between the generations. This kind of information might be beneficial for the marketing strategies that will enable the current lines of goods to be adoptable to the markets of the future (Phillips and Sternthal, 1977: 453). 
In this study, even though there was no difference between the $\mathrm{X}$ and $\mathrm{Y}$ generations with regards to the enjoyment factor, the marketing managers should take into consideration this factor as well in their marketing decision and practices. For instance, in their study regarding consumers' online information search, Maity et al. (2012) found that the enjoyment factor mediated the relationship between search efforts and satisfaction. Therefore, the marketing managers should make efforts for the customers to gain more experience on website enjoyment.

One of the important issues in the online information search behavior is related with the information credibility on the internet. The internet users might use numerous criteria in assessing the information credibility on the web. At this point, the credibility of information available on the web, the credibility of the web/internet itself as media, the credibility of specific message, blog etc. and the credibility of the web sites as a whole can all be used in the assessment of the users. The internet users do not want to make huge efforts in order to assess the credibility of the online information and attach great importance to the professional website design in credibility assessments (Metzger, 2007). Therefore, it will be beneficial for the businesses if the marketing managers pay attention to the design and quality their web sites.

Another field that has grown tremendously today is the social media. The marketing managers should deal with the characteristics of generations and their behaviors of social media use. For instance, in their study in which they investigated the online social network web site addition of the consumers in the Y generation, Nusair et al. (2013) found that the perceived utility and trust were positively related with affective and calculative addition. Therefore, the marketing managers in the sector should try to find ways to strengthen the emotional bond between the users of the Y generation and online social network sites. In this sense, the benefits to be gained by the Y generation while using the online social network websites should be focused on; the groups with similar fields of interest should be provided more information about the destination or about the company and the use of these tools should be made more fun to use.

The internet offers consumers many different ways to share their personal experiences and opinions with other consumers. At this point, opinion platforms are an important information medium that has significant impact over consumers' purchasing and communication behavior. This particular situation offers businesses many opportunities as well as posing some risks (Hennig-Thurau and Walsh, 2003: 64-66). Today, the importance of the social media that has begun to be one of the most important sources of information may also differ from sectoral perspective. For instance, the importance of social media in the field of online tourism has been increasing more and more. This particular situation seems to be one of the problems the tourism businesses that provide information in a traditional way will face. Therefore, tourism businesses should make efforts to be included in various online sources such as both in the social media web sites (such as TripAdvisor, VirtualTourist db.), and in blog sites and social network sites. They should constantly keep track of the dynamics of the technology (Xiang and Gretzel, 2010: 186). The necessity to exist on various online social media tools is also clearly seen in the results of the research carried out Bickart and Schindler (2001). In their study in which they examined the internet forums as consumer information source in a 12-week-period in a student sampling, Bickart and Schindler (2001) found that the consumers who obtained information from online debate forums were more interested in the topics of goods than the customers who 
collected information from the sources set up by the marketers. This particular result reveals that there is a need to support the development of online communities within the business web sites by the companies in order to draw more interest in the categories of goods. Businesses can support it by creating links to the goods-category forums in their own web sites.

Interpersonal online influence and electronic word of mouth (e-Wom) is an important aspect of electronic commerce and one of the most important information source used by the consumers in their decisions to make a purchase (Litvin et al., 2008). E-wom can have a greater impact over consumers' goods assessments, attitudes and decisions in comparison to the traditional marketing communications (Brown et al., 2007). The purposes of consumers' online search of others' opinions can be arranged as; minimizing the risks in making a purchase, purchasing goods and/or services at a cheaper price and having easy access to information (Goldsmith and Horowitz, 2006).

Since the internet is perceived to be a powerful tool for consumers' information search, the marketing managers are very interested in understanding the relationship between consumers' use of the internet for information search and choosing the channel to make the financial purchase (for instance traditional channel or the internet channel). In their study regarding this subject, Shim et al. (2001) found that the intention to search for online paved the way for intention to make a purchase by means of the same media. Therefore, information search and the channel chosen for it should be considered as an extremely significant factor aimed at choosing the method of purchase. Therefore, online sellers should not regard the decision for doing an online search and making an online purchase as an independent process.

As it is the case in every research, the present research also has some limitations. The present study only included the consumers in the $\mathrm{X}$ and $\mathrm{Y}$ generations. Reasons such as costs and time factor caused the number of participants not to be as high as expected. In future studies, working with a more comprehensive sampling and taking the sectoral differences into consideration will help consumers' information and opinion search behavior to be understood better. Besides, the future studies can also consider the web site quality and design based on generations.

\section{References}

Adıgüzel, O., Batur, H.Z. And Ekşili, N., (2014). Kuşakların değişen yüzü ve y kuşağı ile ortaya çıkan yeni çalışma tarzı: mobil yakalılar. Süleyman Demirel Üniversitesi Sosyal Bilimler Enstitüsü Dergisi, 1(19), 165-182.

Anantatmula, V. S., \& Shrivastav, B. (2012). Evolution of project teams for Generation Y workforce. International Journal of Managing Projects in Business, 5(1), 926.

Ayhün, S. E. (2013). Kuşaklar arasındaki farklılıklar ve örgütsel yansımaları. Muğla Sitk1 Koçman Üniversitesi İktisadi ve İdari Bilimler Fakültesi Ekonomi ve Yönetim Araştırmaları Dergisi, 2(1), 93-112.

Barber, N., Dodd, T., \& Kolyesnikova, N. (2009). Gender differences in information search: implications for retailing. Journal of Consumer Marketing, 26(6), 415426. 
Barnes, S. J., Bauer, H. H., Neumann, M. M., \& Huber, F. (2007). Segmenting cyberspace: a customer typology for the internet. European Journal of Marketing, 41(1/2), 71-93.

Baumgartner, H., \& Homburg, C. (1996). Applications of structural equation modeling in marketing and consumer research: A review. International journal of Research in Marketing, 13(2), 139-161.

Behrstock-Sherratt, E., \& Coggshall, J. G. (2010). Realizing the promise of Generation Y. Educational Leadership, 67(8), 28-34.

Bei, L. T., Chen, E. Y., \& Widdows, R. (2004). Consumers' online information search behavior and the phenomenon of search vs. experience products. Journal of Family and Economic Issues, 25(4), 449-467.

Bhatnagar, A., \& Ghose, S. (2004). Online information search termination patterns across product categories and consumer demographics. Journal of Retailing, 80(3), 221-228.

Bhatnagar, A., Misra, S., \& Rao, H. R. (2000). On risk, convenience, and Internet shopping behavior. Communications of the ACM, 43(11), 98-105.

Bickart, B., \& Schindler, R. M. (2001). Internet forums as influential sources of consumer information. Journal of interactive marketing, 15(3), 31-40.

Bilgihan, A., Peng, C., \& Kandampully, J. (2014). Generation Y's dining information seeking and sharing behavior on social networking sites: An exploratory study. International Journal of Contemporary Hospitality Management, 26(3), 349366.

Bolton, R. N., Parasuraman, A., Hoefnagels, A., Migchels, N., Kabadayi, S., Gruber, T., \& Solnet, D. (2013). Understanding Generation Y and their use of social media: a review and research agenda. Journal of Service Management, 24(3), 245-267.

Brown, J., Broderick, A. J., \& Lee, N. (2007). Word of mouth communication within online communities: Conceptualizing the online social network. Journal of interactive marketing, 21(3), 2-20.

Bucic, T., Harris, J., \& Arli, D. (2012). Ethical consumers among the millennials: A cross-national study. Journal of Business Ethics, 110(1), 113-131.

Chiang, K. P., \& Dholakia, R. R. (2003). Factors driving consumer intention to shop online: an empirical investigation. Journal of Consumer psychology, 13(1), 177183.

Choo, C. W., Detlor, B., \& Turnbull, D. (2000). Information seeking on the Web: An integrated model of browsing and searching. First Monday, 5(2), http://firstmonday.org/article/view/729/638, Access Date: 09.10.2016.

Cotten, S. R., \& Gupta, S. S. (2004). Characteristics of online and offline health information seekers and factors that discriminate between them. Social science \& medicine, 59(9), 1795-1806. 
Darley, W. K., Blankson, C., \& Luethge, D. J. (2010). Toward an integrated framework for online consumer behavior and decision making process: A review. Psychology \& marketing, 27(2), 94-116.

Degeratu, A. M., Rangaswamy, A., \& Wu, J. (2000). Consumer choice behavior in online and traditional supermarkets: The effects of brand name, price, and other search attributes. International Journal of research in Marketing, 17(1), 55-78.

Dholakia, R., \& Uusitalo, O. (2002). Switching to electronic stores: consumer characteristics and the perception of shopping benefits. International Journal of Retail \& Distribution Management, 30(10), 459-469.

Diaz, J. A., Griffith, R. A., Ng, J. J., Reinert, S. E., Friedmann, P. D., \& Moulton, A. W. (2002). Patients' use of the Internet for medical information. Journal of general internal medicine, 17(3), 180-185.

Dittmar, H., Long, K., \& Meek, R. (2004). Buying on the Internet: Gender differences in on-line and conventional buying motivations. Sex roles, 50(5-6), 423-444.

Ekici, S., \& Uçak, N. Ö. (2012). İlköğretim öğrencilerinin İnternet'te bilgi arama davranışları. Türk kütüphaneciliği, 26(1), 78-96.

Eysenbach, G., \& Köhler, C. (2002). How do consumers search for and appraise health information on the world wide web? Qualitative study using focus groups, usability tests, and in-depth interviews. Bmj, 324(7337), 573-577.

Fodness, D., \& Murray, B. (1997). Tourist information search. Annals of tourism research, 24(3), 503-523.

Fodness, D., \& Murray, B. (1999). A model of tourist information search behavior. Journal of travel research, 37(3), 220-230.

Forsythe, S. M., \& Shi, B. (2003). Consumer patronage and risk perceptions in Internet shopping. journal of Business research, 56(11), 867-875.

Geçer, A., \& İra, N. (2014). Web ortamında bilgi arama ve yorumlama stratejileri ölçeği'nin Türkçeye uyarlanması. Buca Eğitim Fakültesi Dergisi, (38), 134-147.

Goldsmith, R. E., \& Horowitz, D. (2006). Measuring motivations for online opinion seeking. Journal of interactive advertising, 6(2), 2-14.

Grant, R., Clarke, R. J., \& Kyriazis, E. (2007). A review of factors affecting online consumer search behaviour from an information value perspective. Journal of Marketing Management, 23(5-6), 519-533.

Hennig-Thurau, T., Walsh, G., \& Walsh, G. (2003). Electronic word-of-mouth: Motives for and consequences of reading customer articulations on the Internet. International Journal of Electronic Commerce, 8(2), 51-74.

Ho, C. I., Lin, M. H., \& Chen, H. M. (2012). Web users' behavioural patterns of tourism information search: From online to offline. Tourism Management, 33(6), 1468-1482.

Hodkinson, C., Kiel, G., \& McColl-Kennedy, J. R. (2000). Consumer web search behaviour: diagrammatic illustration of wayfinding on the web. International Journal of Human-Computer Studies, 52(5), 805-830. 
Iacobucci, D. (2010). Structural equations modeling: Fit indices, sample size, and advanced topics. Journal of Consumer Psychology, 20(1), 90-98.

Islam, M., Cheong, T. W., Yusuf, D. H. M., \& Desa, H. (2011). A Study on 'Generation $\mathrm{Y}^{\prime}$ Behaviours at Workplace in Penang. Journal of Applied Sciences Research, 7(11), 1802-1812

Jepsen, A. L. (2007). Factors affecting consumer use of the Internet for information search. Journal of Interactive Marketing, 21(3), 21-34.

Keleş, H. N. (2011). Y kuşağı çalışanlarının motivasyon profillerinin belirlenmesine yönelik bir araştırma. Organizasyon ve Yönetim Bilimleri Dergisi, 3(2), 129139

Kiel, G. C., \& Layton, R. A. (1981). Dimensions of consumer information seeking behavior. Journal of marketing Research, 233-239.

Kim, D., \& Jang, S. S. (2014). Motivational drivers for status consumption: A study of Generation Y consumers. International Journal of Hospitality Management, 38, $39-47$.

Klein, L. R., \& Ford, G. T. (2003). Consumer search for information in the digital age: An empirical study of prepurchase search for automobiles. Journal of interactive Marketing, 17(3), 29-49.

Kulviwat, S., Guo, C., \& Engchanil, N. (2004). Determinants of online information search: a critical review and assessment. Internet research, 14(3), 245-253.

Kumar, N., Lang, K. R., \& Peng, Q. (2005, January). Consumer search behavior in online shopping environments. In Proceedings of the 38th Annual Hawaii International Conference on System Sciences, 175b-175b.

Kupperschmidt, B. R. (2000). Multigeneration employees: strategies for effective management. The health care manager, 19(1), 65-76.

Kurulgan, M. \& Argan, M., (2007). Anadolu üniversitesi öğrencilerinin internet üzerinden bilgi arama davranışları. Atatürk Üniversitesi Sosyal Bilimler Enstitüsü Dergisi, 9(1), 291-304.

Laroche, M., Cleveland, M., \& Browne, E. (2004). Exploring age-related differences in information acquisition for a gift purchase. Journal of Economic Psychology, 25(1), 61-95.

Laroche, M., Saad, G., Cleveland, M., \& Browne, E. (2000). Gender differences in information search strategies for a Christmas gift. Journal of Consumer Marketing, 17(6), 500-522.

Lehto, X. Y., Jang, S. S., Achana, F. T., \& O'Leary, J. T. (2008). Exploring tourism experience sought: A cohort comparison of baby boomers and the silent generation. Journal of Vacation Marketing, 14(3), 237-252.

Lester, D. H., Forman, A. M., \& Loyd, D. (2006). Internet shopping and buying behavior of college students. Services Marketing Quarterly, 27(2), 123-138.

Litvin, S. W., Goldsmith, R. E., \& Pan, B. (2008). Electronic word-of-mouth in hospitality and tourism management. Tourism management, 29(3), 458-468. 
Maity, M., Hsu, M. K., \& Pelton, L. E. (2012). Consumers' online information search: Gen yers' finding needles in the Internet haystack. Journal of Marketing Channels, 19(1), 49-76.

Marketing to Generation Y (2010), Understanding and Appealing to the Millennial Generation", Marketing To Gen Y, September, 1-18.

McFadden, M. (2011-2012), "The Millennial Generation", QUERY Saskatchewan Reading Council, V. 41, N. 1, Fall/Winter, 10-11.

Metzger, M. J. (2007). Making sense of credibility on the Web: Models for evaluating online information and recommendations for future research. Journal of the American Society for Information Science and Technology, 58(13), 20782091.

Morahan-Martin, J. M. (2004). How internet users find, evaluate, and use online health information: a cross-cultural review. CyberPsychology \& Behavior, 7(5), 497510 .

Ng'ang'a, R. M. (2012). The Generation Y Consumer Behavior And Its Influence On Economic Pillar Of Kenya Vision 2030, Research Project In Partial Fulfillment Of The Requirements For The Degree Of Master Of Business Administration (MBA), School Of Business, University Of Nairobi.

Nusair, K.K., Bilgihan, A., Okumus, F. and Cobanoglu, C., (2013). Generation Y travelers' commitment to online social network websites. Tourism Management, 35, 13-22.

Nusair, K.K.; Parsa, H. G., \& Cobanoglu, C. (2011). Building a model of commitment for Generation Y: An empirical study on e-travel retailers. Tourism Management, 32(4), 833-843.

Okay, Ş. (2010). Teknik öğretmen adaylarının İnternet kullanım amaçlarının incelenmesine ilişkin bir araştırma. Makine Teknolojileri Elektronik Dergisi, 7(1), 97-109.

Pan, B., \& Fesenmaier, D. R. (2006). Online information search: vacation planning process. Annals of Tourism Research, 33(3), 809-832.

Park, J., Yoon, Y., \& Lee, B. (2009). The effect of gender and product categories on consumer online information search. NA-Advances in Consumer Research, Vol. 36, eds. Ann L. McGill and Sharon Shavitt, Duluth, MN : Association for Consumer Research, 362-366.

Parry, E., \& Urwin, P. (2011). Generational differences in work values: A review of theory and evidence. International Journal of management reviews, 13(1), 7996.

Peterson, R. A., \& Merino, M. C. (2003). Consumer information search behavior and the Internet. Psychology \& Marketing, 20(2), 99-121.

Phillips, L. W., \& Sternthal, B. (1977). Age differences in information processing: a perspective on the aged consumer. Journal of Marketing Research, 14(4), 444457. 
Ramaswami, S. N., Strader, T. J., \& Brett, K. (2000). Determinants of on-line channel use for purchasing financial products. International Journal of Electronic Commerce, 5(2), 95-118.

Ratchford, B. T., Talukdar, D., \& Lee, M.S. (2001). A model of consumer choice of the Internet as an information source. International Journal of Electronic Commerce, 5(3), 7-21.

Rezabakhsh, B., Bornemann, D., Hansen, U., \& Schrader, U. (2006). Consumer power: a comparison of the old economy and the Internet economy. Journal of Consumer Policy, 29(1), 3-36.

Saigal, B. S., \& Mann, B. J. S. (2010). The mediating role of demographics and time pressure in information search process: A comparative analysis of English and Indian consumers. IUP Journal of Marketing Management, 9(1/2), 7-22

Salahuddin, M. M. (2010). Generational differences impact on leadership style and organizational success. Journal of Diversity Management, 5(2), 1-6.

Schmidt, J. B., \& Spreng, R. A. (1996). A proposed model of external consumer information search. Journal of the academy of Marketing Science, 24(3), 246256.

Schullery, N. M. (2013). Workplace engagement and generational differences in values. Business Communication Quarterly, 76(2), 252-265.

Senbir, H. (2004). Z Son İnsan M1?. 1. Bask1, “O” Kitaplar, İstanbul.

Shim, S., Eastlick, M. A., Lotz, S. L., \& Warrington, P. (2001). An online prepurchase intentions model: The role of intention to search: Journal of retailing, 77(3), 397-416.

Simões, L. \& Gouveia, L. (2008). Consumer Behaviour of the Millennial Generation. III Jornadas de Publicidade e Comunicação. A Publicidade para o consumidor do Séc. XXI. UFP. Porto. 10 de Abril, 1-9.

Sorce, P., Perotti, V., \& Widrick, S. (2005). Attitude and age differences in online buying. International Journal of Retail \& Distribution Management, 33(2), 122132.

Stein, J. (2013). Millennials: The Me Me Me Generation. Time Magazine, 20 May 2013, 1-8.

Sullivan, P., \& Heitmeyer, J. (2008). Looking at Gen Y shopping preferences and intentions: exploring the role of experience and apparel involvement. International Journal of Consumer Studies, 32(3), 285-295.

Tabachnick, B.G. \& Fidell, L.S. (2012). Using multivariate statistics. (6th ed.). New Jersey: Pearson.

Tan, B. (2012). Gen Y talent: How to attract and retain the young and the restless. ABC Technology and Games, http://www.abc.net.au/technology/articles/ 2012/10/31/3622574.htm, Access Date: 10.06.2016.

Teo, T.S.H. (2002). Attitudes toward online shopping and the Internet. Behaviour \& Information Technology, 21(4), 259-271. 
Tsui, B. (2001). Generation Next. Advertising Age, 72 (3), http://adage.com/article/ news/generation /55731/, Access Date: 10.06.2016.

TÜIK, (2015). 2015 yılı adrese dayalı nüfus kayıt sistemi sonuçları. Tarih: 28.01.2016 Sayı: 21507, (http://www.tuik.gov.tr/ OncekiHBArama.do), Erişim Tarihi: 17.10.2016

Uçak, N.Ö. \& Al, U. (2000). İnternet’te bilgi arama davranışları. Türk Kütüphaneciliği, $14(3), 317-331$.

Van der Heijden, H., Verhagen, T., \& Creemers, M. (2003). Understanding online purchase intentions: contributions from technology and trust perspectives. European journal of information systems, 12(1), 41-48.

Ward, M. R., \& Lee, M. J. (2000). Internet shopping, consumer search and product branding. Journal of product \& brand management, 9(1), 6-20.

Weston, R., \& Gore, P. A. (2006). A brief guide to structural equation modeling. The Counseling Psychologist, 34(5), 719-751.

Williams, K. C., \& Page, R. A. (2011). Marketing to the generations. Journal of Behavioral Studies in Business, 3(1), 1-17.

Xiang, Z., \& Gretzel, U. (2010). Role of social media in online travel information search. Tourism management, 31(2), 179-188.

Yalçınalp, S. \&Askar, P., (2003). Öğrencilerin bilgi arama amacıyla internet'i kullanım biçimlerinin incelenmesi. TOJET: The Turkish Online Journal of Educational Technology, 2(4), 100-107.

Yaşa, E. \& Bozyiğit, S. (2012). Kuşağı tüketicilerinin cep telefonu ve gsm operatörleri tercihi: Mersin ilindeki üniversite öğrencilerinin tercihlerini belirlemeye yönelik pilot bir araştırma. Çağ Üniversitesi Sosyal Bilimler Dergisi, 9(1), 2946.

Yelkikalan, N. Akatay, A. \& Altın, E. (2010). Yeni girişimcilik modeli ve yeni nesil girişimci profili, internet girişimciliği ve $\mathrm{Y}, \mathrm{M}, \mathrm{Z}$ kuşağı girişimci. Selçuk Üniversitesi Sosyal ve Ekonomik Araştırmalar Dergisi, 14(20), 489-506.

Yoon, C. (1997). Age differences in consumers' processing strategies: An investigation of moderating influences. Journal of Consumer Research, 24(3), 329-342.

Zgódka, M. (2011, September). Influence of search engines on customer decision process. In Computer Science and Information Systems (FedCSIS), 2011 Federated Conference on, 341-344.

Zhang, J.J., Fang, X., \& Liu Sheng, O. R. (2006). Online consumer search depth: Theories and new findings. Journal of Management Information Systems, 23(3), 71-95.

Zickuhr, K. (2011). Generations and Their Gadgets, A Project of the Pew Research Center, (http://pewinternet.org/Reports/2011/Generations-and-gadgets.aspx), Access Date: 10.06.2016. 